Article

\title{
The Sustainability of Cruise Tourism Onshore: The Impact of Crowding on Visitors' Satisfaction
}

\author{
Silvia Sanz-Blas, Daniela Buzova *(D) and Walesska Schlesinger \\ Department of Marketing, University of Valencia, 46022 Valencia, Spain; silvia.sanz@uv.es (S.S.-B.); \\ m.walesska.schlesinger@uv.es (W.S.) \\ * Correspondence: daniela.buzova@uv.es
}

Received: 27 February 2019; Accepted: 9 March 2019; Published: 13 March 2019

check for updates

\begin{abstract}
The sustainability of cruise tourism has been questioned in relation to its negative effects on ports of call, among which crowding has recently become more pronounced. However, an understanding of how crowdedness influences cruise tourists' experience onshore is lacking. The study analyzed online reviews on onshore experiences in the main European ports of call through Leximancer, an automated text analytics software. The results revealed that the perceived destination crowding was not always negatively evaluated by tourists, but was also discussed as a factor adding up to the authenticity of the visit under certain circumstances. Nevertheless, the evidence indicates that only human crowding might be positively assessed, while the spatial crowdedness was always reported as detracting from the enjoyment of the visit. The analysis also showed that the crowding phenomenon was represented differently in the accounts of the low, average and high satisfaction cruise tourists' groups. The role of the guide, as well as the attractiveness of the sightseeing were identified as factors that can ameliorate the negative effect of crowding on the destination visit. The findings yield relevant implications for all actors involved in the cruise tourism activity, which should manage destination crowdedness in a more sustainably innovative way.
\end{abstract}

Keywords: sustainability; crowding; cruise tourism; Leximancer; satisfaction; innovation; port of call; eWOM

\section{Introduction}

The tourism sector plays a major role in the global economy, contributing to $10.4 \%$ of the Gross World Product and representing 1 out of every 10 jobs in 2017 [1]. One particular type of tourism that has witnessed a significant growth worldwide in the last decade, compared to other tourism products, is cruise tourism [2]. The surge in cruise tourism demand is especially pronounced in Europe, where the number of people purchasing a cruise holiday has increased from 4.05 million in 2007 to 6.96 million in 2017 [3].

This rapid growth should be grounded in the principles of sustainability, which implies that suppliers should not only be concerned about economic profits, but also embrace their social and environmental responsibilities [4]. A high number of cruise arrivals at ports of call may result in destination crowding [5]. Exploring how visitors perceive the crowds of tourists is essential, as it can deteriorate the quality of the destination experience, and negatively affect their post-visit behavior (i.e., recommend and revisit the port of call).

Although crowding has become a significant issue for the tourism industry [6,7], to date, there are few studies that have examined its effect on tourist experience [6-12], and no single study that has analyzed cruise tourists' perception of crowding at port of call destinations. Furthermore, previous crowding studies have mainly adopted quantitative methods, while qualitative approaches have been underutilized. 
In view of the above, the purpose of this study is to explore cruise tourists' perceived crowding at the main European ports of call, and to examine its impact on destination visit satisfaction through the analysis of online reviews. This study therefore fills a major gap in the tourism literature on overcrowding by exploring the role of crowding perception in both, positively and negatively evaluated cruise destination experiences.

The remaining part of the paper is structured in four parts. It starts with sustainable destination tourism models, followed by examining the concept of tourism crowding. The forth section is concerned with the methodology of the study, addressing the advantages and weaknesses of using Leximancer. The fifth section analyses the results of the study, while the sixth provides the research conclusions. Finally, the last sections address the discussion of the results, the practical implications of the study, as well as the research limitations and the future research lines.

\section{Sustainable Tourism}

Achieving a sustainable tourism model has become a major challenge for travel destinations in Europe in recent years $[13,14]$. The steadily growing economic impact of tourism, together with the international debate on sustainable development, which pursues to make the economic interests of the sector compatible with the environmental and social constraints of the destination area, leads to a pressing need for a thorough reflection on tourism sustainability [11].

Numerous definitions of sustainable tourism have been proposed throughout the last decades, but most of them reflect the importance of a harmonious interaction between tourists and local communities [15]. Sustainable tourism can be defined as the development of tourism activities with a balance between the environmental, economic, and socio-cultural aspects, so as to ensure its long-term sustainability, according to the United Nations Environment Programme (UNEP) and World Tourism Organization (WTO) [16]. Sustainable tourism implies meeting the needs of the present tourists and destinations while providing opportunities for further development, preserving the world heritage, ecological integrity, biological diversity, and life-support system. The principles of sustainability can be applied to all types of tourism including mass-market tourism and the diverse niche or tourism products.

Sustainable tourism activities mainly include the environmental, economic, social and cultural aspects of development. A balance among these four pillars should be maintained to ensure the sustainability of the tourism sector in the short and long run [17]. To achieve sustainability, the negative effects of tourism activities on the environment, society and economy should be reduced.

The numerous interpretations of the notion of sustainable tourism hint at the differing approaches used by researchers, policy-makers and other stakeholders [18]. In this regard, researchers assert that different understandings of sustainable tourism are suited for different circumstances $[15,19]$. Hence, sustainable tourism should not be understood as a rigid framework, but as an 'adaptive paradigm which legitimizes a variety of approaches according to specific circumstances' [19].

Reducing the negative tourism effects by boosting the tourism benefits into the right direction is the greatest challenge of sustainable tourism $[17,20]$. For instance, a profitable and ecologically sustainable industry can provide satisfying experiences for visitors, as well as improve residents' life quality [21].

There is, nevertheless, some ambiguity. Past research maintains that mass tourism is the opposite of sustainability $[15,22,23]$. "When sustainable tourism has been applied to the industry, more emphasis has been given to tourism's effects upon the environment and economy, rather than to factors related to its effect on communities" [24].

The seasonality associated with tourism activity presents a number of negative impacts that could affect the sustainability of destinations, which go beyond the economic costs, but encompass social and environmental aspects [14]. High visitor concentrations at certain times of the year imply that some destinations suffer stronger impacts [25]. Martín et al. [26] classified them as follows: Environmental (natural resources overuse and massive waste generation), socio-cultural (loss of 
residents' quality of life and tourist dissatisfaction) and economic (unstable employment, decreased competitiveness, and profitability difficulties in the long run). One of the strategies employed to reduce these impacts is to spread the flow of tourists more evenly across the year, so as to obtain a more balanced demand distribution. Hence, tourism crowding management is essential in terms of controlling and redistributing the number of tourists, aiming at ameliorating perceived crowding. Controlling for perceived crowding is crucial not only for a sustainable destination development, but also for achieving tourist satisfaction [27].

\section{Tourism Crowding}

Early studies define a situation as crowded when the presence of others results in interference with one's comfort [28]. Crowding produces stimulus overload, occurring when there is inappropriate or unpleasant contact with other individuals [29]. Furthermore, crowding can be viewed as a situation in which the presence of other people restricts individual's range of choices or hinders one's ability to pursue goals and perform certain activities [30,31]. In this sense, crowding is associated with the notion of carrying capacity [32]. If an overload of the carrying capacity is the starting point of an unsustainable destination model, crowding clearly has a negative effect on it. Crowdedness, therefore, implies exceeding the maximum number of people that can visit a destination simultaneously, leading to externalities in the physical, economic, and socio-cultural environment and diminishing visitors' satisfaction [11,33]. Crowding, thus, refers to a certain level of destination saturation [33].

In the tourism domain, the perception of crowdedness has been analyzed in urban areas [7,8,11,34,35]; festivals [9], tourist attractions [36,37], cruise ships [38] and outdoor settings such as natural parks [6, 10,39-42], or mountains [12]. The existing research shows mixed results on the effect of crowding on behavioral outcomes.

A review of the literature reveals that tourists' perception of crowding depends on a wide range of factors: (i) Personal characteristics (e.g., motivations, expectations, previous experience, nationality, length of stay) $[6,11,33,37,43,44]$; economic factors (income and expenditure) $[11,33,37]$; the characteristics of other tourists encountered (i.e., behavior, interaction with others and similarity) [11,44-46]; as well as the situational variables of the environment (i.e., quality of the facilities, number of tourists, destination design, availability of resources and places of contact) $[11,33,37,46-48]$.

In regards to crowding consequences, past research suggests that crowding perception affects the quality of the experience, as well as tourists' affective response and satisfaction $[6,9,11,12,49,50]$. Research investigating the relationship between crowding perception and satisfaction has yielded mixed findings. There are studies demonstrating a significant negative effect of crowding on tourist satisfaction [12,51]. Some researchers, though, report a weak [52,53], or even a non-significant correlation between the two variables [6]. Interestingly, evidence for the positive association between crowding and tourist satisfaction has also been found, [8,54], particularly when visitors look for hedonic experiences [54], when the level of crowding does not exceed the expectations or when the perception of crowdedness is relatively low $[8,55]$. In this regard, it can be concluded that a crowding perception is not always negative, but can even contribute to tourist's experience and satisfaction $[7,9,11,56]$.

Crowding in tourism studies has usually been measured with a single question [11,57]. However, this approach fails to reflect the cognitive and physiological states inherent to crowding perception [6]. Crowding is posited as a multidimensional construct, comprising two dimensions: Human (i.e., full of people) and spatial (i.e., restricted movement) [9,58]. Both types of crowding may influence customers' behaviors either positively or negatively [7,58] Recently, Li et al. [6] proposed three dimensions to assess crowding: Neutral, personal and social, reflecting not only the perception of a physical constraint, but also the conflict of interests with other tourists at the destination, and internal conflicts among tourists resulting from that interaction. There are several theoretical approaches that can guide the interpretation of the online reviews describing the "good crowding" effect: The Manning theory, the social motivation theory, the social identity theory and the flow theory. Several theoretical perspectives 
guide the study of the negative side of crowding: Social interference, stimulus overload and traffic flow theory $[9,10]$.

To the best of the authors' knowledge, there is currently only one study that uses a qualitative approach to inquire crowding [7], while exploratory research is much needed to expand on its relation to destination sustainability.

In recent years, the concept of crowding has frequently been associated with cruise tourism $[59,60]$. While cruise ship arrivals bring economic benefits to the destinations, the negative impacts of this economic activity, such as congestion and overcrowding of ports of call, the sea contamination and the excessive use of resources should also be considered [61,62]. Previous studies indicate that, in general, the aforementioned factors affect residents' quality of life, as well as tourist satisfaction [61] and even deteriorate their destination experience and the sustainability of the tourism model [63]. Research to date has not yet explored the perception of crowding of cruise tourists and how it influences their satisfaction with the port of call experience.

\section{Methodology}

\subsection{Information Source and Data Collection}

To explore cruise tourists' perception of crowding, the study analyzed online reviews on European ports of call published on the leading cruise website cruisecritic.com. Data from cruisecritic.com have previously been used to assess various cruise-related topics such as passengers' cruise ship satisfaction and evaluation of shore excursions [64-66]. Leveraging available online information for advancing cruise tourism research has been suggested as a research line by Papathanassis [67].

Reviews on shore experiences in the key European ports of call (in terms of cruise passengers) were collected by means of a web crawler in December 2018. According to CLIA Europe [3], the following ten ports of call received the largest number of cruise tourists in the period 2013-2017: Marseille (France), Tenerife (Spain), Naples (Italy), Valletta (Malta), Dubrovnik (Croatia), Mykonos (Greece), Istanbul (Turkey), Côte d'Azur, Corfu (Greece) and Santorini (Greece). Overall, 2202 reviews were collected of which the opinions on the shore experience in Naples, Santorini, Marseille and Dubrovnik were most numerous.

Together with the text body of the review, the satisfaction rating of the experience and the date of the visit, information on author's review experience (number or published reviews) and cruise ship brand was also gathered. Unfortunately, data on reviewers' gender, origin or age was not available and therefore, the sociodemographic profile of the reviewers could not be established.

\subsection{Data Analysis}

The automated text-mining software Leximancer was used to analyze the content of the reviews. Leximancer is a "relatively new method for transforming lexical co-occurrence information from natural language into semantic patterns in an unsupervised manner" [68]. The software is based on semantic and relational algorithms, which first "learn" categories of concepts from the text corpus, code the text segments accordingly and finally, analyze the relationships among the concepts.

The obtained results are presented by means of colorful maps depicting underlying themes (groups of concepts), concept frequency and connectedness. Each theme is represented by a circle containing several interrelated concepts, and the relative importance of each theme is indicated by its size and brightness (i.e., the bigger and brighter the circle, the more important the identified theme). The distance between themes and concepts on the map depicts the degree of relatedness among them, with closely situated concepts co-occurring more frequently in the corpus. Apart from the initial exploratory map generated by Leximancer, the data can be profiled per categories of interest (e.g., gender, year of posting, ratings of satisfaction). 
When compared to other qualitative research instruments such as NVivo and Atlas.TI, Leximancer offers a number of advantages [69]. First of all, unlike other qualitative tools, this software does not require any previously established code categories. Due to the automated concept extraction in Leximancer, a quicker identification of concepts is possible, which results in time saving. Furthermore, reaching intercoder agreement is not an issue with Leximancer, as the software uses its own algorithm based on lexical co-ocurrence to conduct the content analysis. Also, because minimum researcher intervention is needed in mining the text corpus, the researcher bias is reduced, and the results are mode reliable. Whilst Leximancer offers the above mentioned advantages, it also has some limitations. For example, the software is not able to identify the style or tone of voice of the textual statements. Another weakness of Leximancer is that, even though the software performs automatic content analysis, the researchers still need to read the text passages to make sense of the words that the algorithm has determined as concepts or themes to understand their meaning in a context.

Leximancer has been used to assess corporate sustainability [70], analyze the concept of entrepreneurial ecosystem [71] and explore the sustainable supply chain management trends [72], among others.

The performed data analysis includes two stages: (i) A general overview of the themes underlying cruise tourists' onshore experience narratives describing crowding and (ii) an analysis of different satisfaction rating groups' perceptions of crowding. Firstly, out of the collected 2202 reviews from cruisecritic.com, only those comments containing the word "crowd" or its derivatives (e.g., crowds, crowded, crowding) were used as data input for the automated thematic content analysis performed by Leximancer. Visualizing the most frequent concepts and topics contained in cruisers' narratives about their destination visit helps understand the context and the significance of the crowding perception in the general experience. It should be noted that although the software automatically defines a list of concepts not all of them provide meaningful information, and the researcher has to review them carefully [73].

Initially, Leximancer identified 45 concepts, but we had to remove some of them, as they were either name-like concepts (i.e., destination or sightseeing attractions names such as Santorini and Pompeii) or were too generic verbs and adverbs (e.g., take, down) and thus were not providing any insight on the analyzed information. The final concept list was composed of 34 concepts. In a second stage, reviews' satisfaction scores were chosen as mapping concepts, which produced a new view of the map with satisfaction categories correlated with certain concepts and themes.

\section{Results}

\subsection{Representation of Crowding in the Overall Cruise Tourists' Onshore Experience}

Once the concept list was adjusted, a map showing the most relevant themes and concepts representing cruise tourists' overall experience onshore was produced (see Figure 1). 


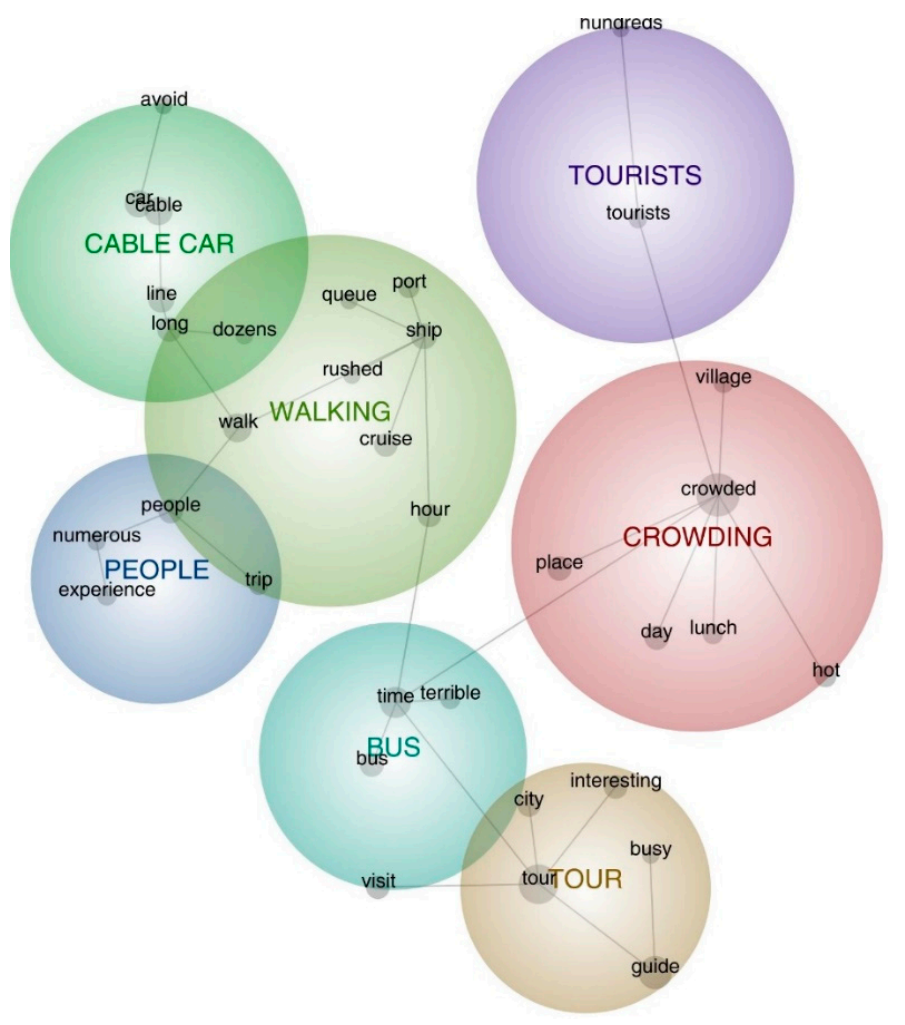

Figure 1. Overall concept map representing cruise tourists' onshore experience.

The map includes 34 concepts, clustered in seven themes: "crowding", "tour", "walking", "bus", "cable car", "people" and "tourists". The most relevant theme is "crowding", encompassing concepts such as "place", "village" and "hot". The concepts in this theme mainly refer to the physical spaces where crowding was mostly perceived. Some of the comments representing this theme include the following:

"10,000 people on Santorini (4 ships). Uncomfortably crowded."

"You need to get to Oia village early as it has tiny streets and gets very crowded with tourists."

"We took the 8:30 am shuttle, as we wanted to walk the walls before it got crowded and hot and it worked out well."

"The village of Oia is beautiful, but very crowded and overly commercialized."

"Tour" emerged as the second most mentioned theme in cruise tourists' narratives about their onshore stay. This theme is associated with the concepts of "guide", "city" and "interesting", and is highly connected with the "bus" theme, as most cruise passengers visit ports of call on bus tours. "Bus", in turn, includes the adjective "terrible", indicating the satisfaction with the transport service, and the concept of "time", denoting the excessive amount of time spent inside the bus instead of sightseeing.

Below are some typical comments illustrating the above concepts and themes:

"I wished that we could have spent more time with our wonderful and interesting guide, Italio, at Pompeii."

"Tour guide was great, very very crowded on a bank holiday."

"It was nice to see the ruins, but the trip back was difficult because they were not prepared for the trip back and we got into a bus full of people, it was terrible." 
"Visited Oia and Santo winery, could have spent a bit more time in Oia, the winery visit was very crowded with lots of buses there at the same time."

"I found that this excursion spent much time bussing us to different levels of the island."

Another theme refers to "walking", and represents the third most relevant topic identified in cruise tourists' narratives about their onshore experience. The theme includes concepts such as "port", "ship" and "queue" and reveals that walking distances and difficulties in moving around the port of call are important aspects for cruise passengers.

The following review excerpts express the aforementioned ideas:

"Hard to walk around with so many people on the narrow streets."

"We had to queue for the cable car for an hour but it was worth it as the walk down was very difficult and slippery."

"To get back to the ship we recommend walking the donkey trail in Fira to the harbour-it is 20 minutes."

Further themes emerging from the narratives are "cable car" and "people". Regarding the topic of "cable car", reviewers most frequently mentioned the concepts "line" and "long" and "dozens". The "people" theme is associated with "numerous", "experience" and "trip".

Some typical comments include the following:

"To get back to the ship we recommend walking the donkey trail in Fira to the harbor-it is 20 minutes

(smelly) but worth avoiding the queues for the cable car which can take up to an hour."

"The place is beautiful but very crowded. And the line ups for the cable car were crazy."

"The city is lovely, but there were so many people it was hard to walk."

The last dominant theme is about other "tourists", which have been frequently defined as "hundreds". A representative comment of this theme is the one above:

"It was impossible to walk around with all the tour buses unloading hundreds of tourists."

The results reveal that, at an overall level, cruise tourists experiment the sensation of crowding strolling at the port of call, during the bus transfers and at the attraction sites. The queues and waiting time add up to the negative experience onshore, as tourists perceive it as a wasted time. However, those tourists who had a guided tour seem to be more satisfied with their onshore visit, thanks to guides' efforts to avoid the congested sites and routes.

\subsection{Representation of the Crowding Perception by Different Satisfaction Groups}

This section provides an account of how the perception of crowding was represented in reviews from different satisfaction groups. Satisfaction levels (ratings 1 to 5) were used as mapping concepts, which resulted in five themes: "crowded", "tour", "cable car", "cruise" and "trip" (see Figure 2). 


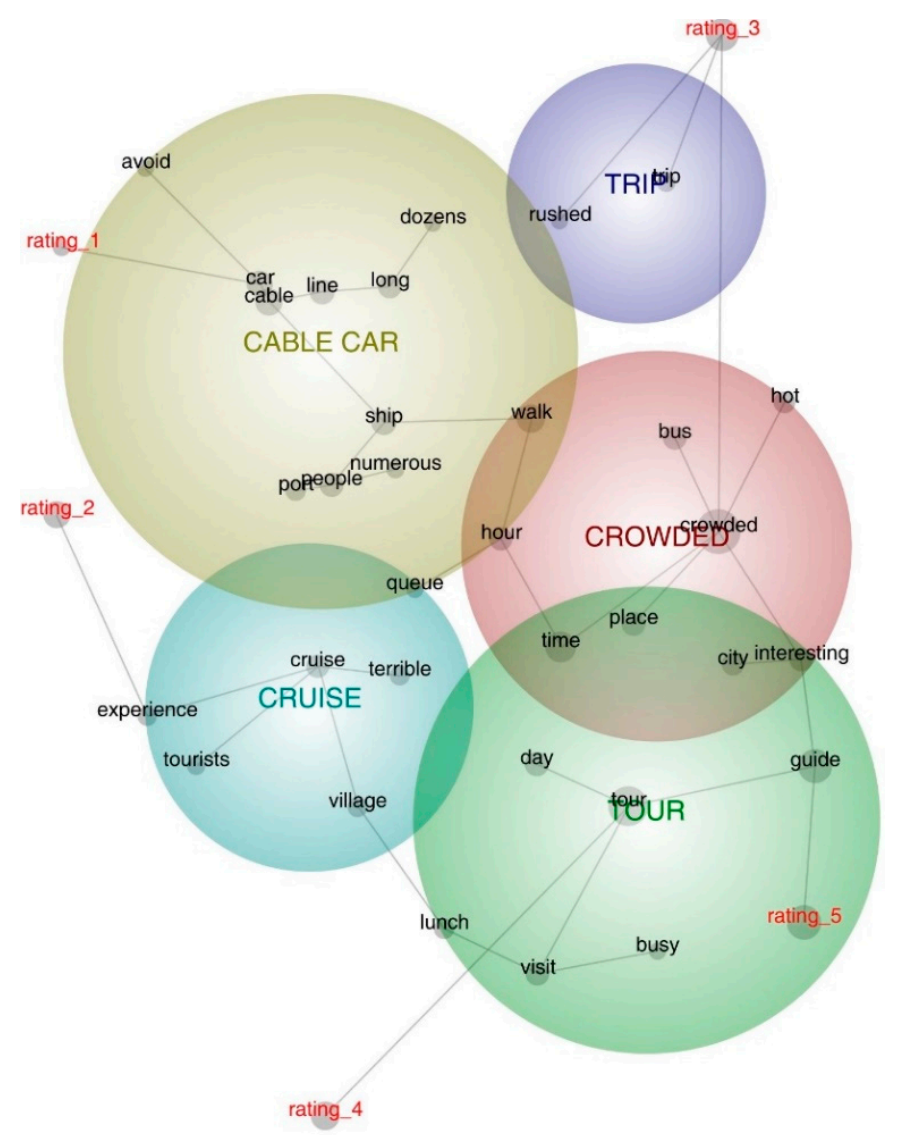

Figure 2. Representations of the onshore experience: different satisfaction groups.

Figure 2 indicates that the five satisfaction groups viewed the crowding experience differently during their onshore stay. This is inferred by the fact that some concepts and themes are more closely associated with particular rating groups, suggesting that the content of the narratives differed significantly.

The narratives of the reviewers that rated their port of call experience the highest (i.e., 5 points) are linked with the concepts "guide", "interesting" and "city", while the sense of crowding was not always reported as a negative one. Typical reviews include:

"Our tour guide (looked just like Jeremy Renner) was exceptional! He was able to show us the most interesting parts of the city in just 3 hours [ ... ] No one spoke English, it was very retro, the soccer games were on, the crowd was lively and what a great day in Dubrownik!"

"'Private Custom Tour Santorini.' Dimitris our private tour guide and driver exceeded our expectations! Dimitris took us to some wonderful places that bus tours simply can't navigate."

"Fabulous guide made all the difference in bringing the ruins to life and knowing the tricks of avoiding the crowds."

"This included guided walking tour was again very interesting. We mixed and mingled with the crowds of Italian speaking people while being guided very well by our English speaking tour guide."

"Not enough time to explore this beautiful place. Our excellent tour guide got us into palace before all the crowds."

"Only had a short time there but thanks to an excellent guide saw a lot (and away from the crowds too)." 
"Tour" is the concept most frequently discussed by those tourists who evaluated their shore experience with 4 out of 5 points (i.e., very good). Other concepts related to a 4-rating experience include "lunch", places to "visit" and "busy". Some reviewers declared that they would have rated their onshore visit with 5 points if it had not been for the overcrowding.

Below are some comments pertaining to this satisfaction group:

"Naples itself is a big busy city, so not sure I would've wanted to spend much time there. We did an NCL small-group tour to the Amalfi coast where we visited Positano, then Sorrento for lunch, then a guided tour of Pompeii. It was a great tour-but I'm giving it 4 stars instead of 5 because of the traffic on the Amalfi coast and the unfortunate overcrowding in Positano and Sorrento."

"Great place to visit and great tour, but lots and lots of tourists! Wish I knew the answer to these overcrowded tourist hotspots."

"We were able to spend enough time at the Blue Mosque and Topkapi palace, although its museums were more crowded than any I have ever seen. We had time for lunch and an hour in the Grand Bazaar on our own. It was enough. I would have been totally lost if I had tried to go on my own so I am satisfied with the excursion."

The reviews of those cruise tourists who reported that their onshore experience was of "average" quality (i.e., 3 rating points), were most frequently associated with the concepts of "crowded", "rushed" and "trip". In this case, the perception of crowding had a relevant negative impact on the visit, even though reviewers admitted that it was an "interesting trip". The following comments show the aforementioned ideas:

"The tour itself felt a bit rushed-I'd have preferred a transfer only rather than the guided tour as there was a lot to see, but shuffling along in a group in the crowds made for slow progress."

"It was very crowded and we couldn't always see what the guide was trying to show us."

"An otherwise interesting trip to a reasonably interesting place (with decent history) somewhat overshadowed by the large delay getting out thanks to dozens of coaches crowding a road barely wide enough for one."

The group of reviewers who rated their onshore experience with only two rating stars, thus indicating a relatively poor level of satisfaction, complained about the "terrible" "experience" they had due to the large amount of "tourists". Some typical comments include the following:

"But this experience on a day with 4 ships in port was anything but magical due to massive crowding and the awful options to get back to port."

"The crowds in Ola were terrible and things got dangerous in narrow streets we had to pass through."

"We went to Oia Village, so crowded and hot. It was impossible to walk around with all the tour buses unloading hundreds of tourists."

Lastly, the comments of those cruise tourists who were least satisfied with the onshore experience (rating = 1) were strongly linked with the "cable car" theme. The "long" "lines", the "numerous" "people" and the large distances they had to "walk" from the cruise "ship" until the places of interest were mentioned as the main causes of dissatisfaction.

Below are some review excerpts that illustrate the negative contribution of crowding on the onshore experience:

"1 hour in Amalfi, where we were constantly in fear of being run down by autos whizzing through narrow, overcrowded streets. Highly disappointing." 
"Extremely crowded, cruise description was not even close to what was described. Spent over half the allotted time on a bus or in line to get onto the cable cars to get back to the ship."

"Very long wait for the cable car!!! Very disappointing."

In summary, while crowding was perceived by all satisfaction groups, its impact on the onshore experience differed significantly. The findings can be interpreted in the following way: The negative effect of crowding was ameliorated by the tour guide, the attractive sightseeing and the gastronomy of the places visited. In contrast, the spatial crowding and the lack of the aforementioned elements in the onshore visit are suggested as the reasons underlying the low levels of satisfaction.

\section{Conclusions}

The aim of the study was to assess how cruise tourists perceive and describe the crowding phenomenon as part of their onshore experience. The research confirms the widely acknowledged tourists' negative reactions towards crowding at attraction sites. Nevertheless, evidence of good crowding perception was also found. The analysis identified that the different satisfaction groups showed a varying degree of sensitivity toward crowding. The results reveal that those tourists, who rated their onshore experience as very good, reported perceptions of human crowding. While the encountered tourist congestion was also emphasized by the lower satisfaction groups, the highly satisfied cruise tourists showed crowding tolerance and even described it as "good crowding" [7]. This was especially the case when the interaction with the crowd adds to the experience (e.g., immersion in a crowd of locals speaking a different language added to the authenticity of the travel experience, rather than ruin it).

Another interesting finding related to the crowding perception reported by the highly satisfied cruise tourists is the role of the tour guide in mitigating the negative congestion effects by providing space orientation to avoid the crowds. It should also be noted that the guide's contribution to the positive evaluation of the onshore experience was also due to his/her knowledge about the destination, which was also frequently reported by the reviewers. Thus, it might be inferred that informative tour guides with good storytelling and planning skills can compensate, to a certain extent, for the negative effect of the sensation of crowding on the overall tourist experience.

The guided tour was also the most relevant concept representing the narratives of the reviewers who rated their onshore experience with 4 points. While this group of tourists reported having perceived human crowding, aspects of the visit such as the lunch they had, and the interesting attraction sites (e.g., cathedrals, heritage sites, etc.) helped to offset the negative crowding impressions. However, some tourists pertaining to this group admitted that the crowding has detracted from their onshore experience, which they would have otherwise rated as excellent.

The tourists who reported an average onshore experience were more sensitive to the crowding, which had "ruined" the interesting visit to the ports of call. In this case, the reviewers described both, human and spatial crowding, i.e., not only congestion of people was encountered, but also difficulties in moving freely at the destination. This group of visitors acknowledged the tourist appeal of the visited ports of call, but this was, apparently, not enough to remedy the inconveniences caused by crowdedness.

As for the impressions shared by the unsatisfied group of tourists, they were almost exclusively focused on the crowding issue, pointing out that the encountered crowdedness (both human and spatial) has superseded the attractive sightseeing as the core of the onshore visit.

\section{Discussion}

Overall, the findings suggest that cruise tourists perceive human and spatial crowding, which might not only be negative in nature, but also positive, in terms of augmenting the authenticity of the travel experience. While the evidence shows that the perception of crowding in general diminishes tourist satisfaction (and thus is in line with past research (e.g., [6]), differences have been observed in 
the specific impact of human and spatial crowdedness. Unlike spatial crowding, which has only been reported as an impediment for enjoying the visit, human crowdedness has sometimes been considered as "good crowding", adding up to the local experience. Thus, an interesting finding emerging from this research is that crowding can have not only negative, but also positive consequences on tourist experience and satisfaction $[7,9,11,34,56]$.

Another noteworthy finding is the role of the guide in attenuating the negative impact of crowding on the port of call visit by avoiding the crowds of tourists in space and time. This result is in line with existing studies emphasizing that a reasonable level of crowding makes the perception of congestion and lack of space more bearable [8].

Several online reviews described the "good crowding" effect, which can be interpreted in the light of different theoretical perspectives. For some of the cruise tourists, being part of the crowd has contributed to a greater enjoyment of the visit, as the multitude of tourists is indicative of the importance and attractiveness of the port of call destination (the Manning theory). In the case of those cruise tourists who have chosen a guided tour as the visit format, being part of a group of tourists who share the same interests, has contributed to a greater extent of socialization, and a more satisfying experience (social motivation and social identity theory). Furthermore, some tourists declared being so engaged in the visit and delighted by the tour, that the crowd around them has gone almost unnoticed (flow theory).

Similarly, the evidence of the negative side of crowding can also be explained through existing theories. For example, some tourists described the crowding as a circumstance that was impossible to manage and prevented them from satisfying their sightseeing needs (social interference theory). Others reported excessive undesired social interactions (stimulus overload theory), which restricted their mobility (spatial crowding) and made the traffic flow uncontrollable (traffic flow theory) [9].

\section{Practical Implications}

The findings yield important practical implications for all the organizations involved in the management of cruise tourists' flows (i.e., DMOs, cruise ship companies, guided tour businesses, etc.). It is strongly recommended to create strategies to more efficiently manage the traffic of tourists in a way that reduces spatial crowdedness, which will, in turn, increase the satisfaction with the visit. However, while local tourism authorities should be responsible for distributing tourists' flows in the destination, the cruise industry can also contribute to reduce the crowdedness in ports of call by considering the cruise traffic when planning the itineraries, and not the fuel cost mainly [74].

The positive effects of crowding should also be leveraged by informing those tourists, who seek to immerse into the local ambience, about the places where residents usually gather. DMOs are also advised to encourage the purchase of guided tours, as the results of the study emphasize their mitigating effect on tourists' crowding perception. One way to achieve this is through more affordable prices of cruise excursions and local company's guided tours.

In summary, all organizations involved in cruise tourism management have to adopt sustainable innovation practices in order to avoid the negative consequences of human and spatial crowding. In reaching this purpose, coordination among the different actors involved in cruise tourism is essential to secure the sustainability of this economic activity.

\section{Limitations and Future Research}

Finally, some research limitations have to be acknowledged. The study has analyzed crowding perceptions in the main European cruise ports of call, which makes these findings less generalizable to the rest of cruise regions. Hence, future studies could compare crowding perceptions across various cruise regions (e.g., the Caribbean, Asia-Pacific). Also, the study is limited by the analysis of reviews written in English, authored by predominantly English-speaking cruise tourists such as US and UK citizens. A further study could collect reviews written in other languages and check if the results still hold. Assessing the cross-cultural crowding perceptions could provide interesting findings. A 
third limitation lies in the use of one single source of data- cruisecritic.com. While this is the most relevant online platform for cruise-related information, other sources such as Tripadvisor or cruise blogs can be used to extend the validity of the results by increasing the sample size. Although the current study is based on a relatively limited sample of cruise tourists, the findings suggest the key role of tour guides in tackling tourists' negative crowding impressions. In this regard, further research is required in order to determine the mechanism through which guides cope with crowding, and thus are able to significantly enhance visitors' experience onshore. A natural progression of this piece of work is to include the perception of crowding in tourist behavior structural models, and thus assess its relationship with antecedent and outcome constructs.

Author Contributions: Conceptualization, S.S.-B. and D.B.; Methodology, D.B. and S.S.-B.; Software, D.B.; Writing - original draft preparation, S.S.-B. and W.S.

Funding: This research was funded by Generalitat Valenciana, grant number AICO/2017/120 and Ministerio de Ciencia, Innovación y Universidades de España, grant number FPU14/03828.

Conflicts of Interest: The authors declare no conflict of interest.

\section{References}

1. WTTC. Travel \& Tourism Economic Impact 2018 World. 2018. Available online: https://www.wttc.org/-/ media/files/reports/economic-impact-research/regions-2018/world2018.pdf (accessed on 12 February 2019).

2. UNWTO. UNWTO Tourism Highlights: 2018 Edition. 2018. Available online: https:/ /www.e-unwto.org/ doi/pdf/10.18111/9789284419876 (accessed on 12 February 2019).

3. CLIA. Contribution of Cruise Tourism to the Economies of Europe 2017. 2018. Available online: https: //www.cliaeurope.eu/images/Reports/2017_Europe_Economic_Impact_Report_-_20thJune.pdf (accessed on 14 January 2019).

4. Garay, L.A. Luces y sombras del turismo de cruceros: El caso de Barcelona. Documents d'Anàlisi Geogràfica 2015, 61, 563-580. [CrossRef]

5. Van Bets, L.K.; Lamers, M.A.; van Tatenhove, J.P. Governing cruise tourism at Bonaire: A networks and flows approach. Mobilities 2017, 12, 778-793. [CrossRef]

6. Li, L.; Zhang, J.; Nian, S.; Zhang, H. Tourists' perceptions of crowding, attractiveness, and satisfaction: A second-order structural model. Asia Pac. J. Tour. Res. 2017, 22, 1250-1260. [CrossRef]

7. Popp, M. Positive and negative urban tourist crowding: Florence, Italy. Tour. Geogr. 2012, 14, 50-72. [CrossRef]

8. Díaz-Sauceda, J.; Palau-Saumell, R.; Forgas-Coll, S.; Sánchez-García, J. Cross-border tourists' behavioral intentions: The Green Line of Nicosia, Cyprus. Tour. Geogr. 2015, 17, 758-779. [CrossRef]

9. Kim, D.; Lee, C.K.; Sirgy, M.J. Examining the differential impact of human crowding versus spatial crowding on visitor satisfaction at a festival. J. Travel Tour. Mark. 2016, 33, 293-312. [CrossRef]

10. Luque-Gil, A.M.; Gómez-Moreno, M.L.; Peláez-Fernández, M.A. Starting to enjoy nature in Mediterranean mountains: Crowding perception and satisfaction. Tour. Manag. Perspect. 2018, 25, 93-103. [CrossRef]

11. Neuts, B.; Nijkamp, P. Tourist crowding perception and acceptability in cities: An applied modelling study on Bruges. Ann. Tour. Res. 2012, 39, 2133-2153. [CrossRef]

12. Zehrer, A.; Raich, F. The impact of perceived crowding on customer satisfaction. J. Hosp. Tour. Manag. 2016, 29, 88-98. [CrossRef]

13. European Economic and Social Committee. Opinion of the Economic and Social Committee on Social Tourism in Europe. Off. J. Eur. Union 2006. Available online: http:/ / eur-lex.europa.eu/legal-content/EN/ TXT/?uri=CELEX\%3A52006IE1155 (accessed on 23 January 2019).

14. Cisneros-Martínez, J.; McCabe, S.; FernándezMorales, A. The contribution of social tourism to sustainable tourism: A case study of seasonally adjusted programmes in Spain. J. Sustain. Tour. 2018, 26, 85-107. [CrossRef]

15. Hritz, N.; Cecil, A. Investigating the Sustainability of Cruise Tourism: A Case Study of Key West. J. Sustain. Tour. 2008, 16, 168-181. [CrossRef]

16. UNEP; UNWTO. Making Tourism More Sustainable—A Guide for Policy Makers; United Nations Environment Programme: Paris, France; World Tourism Organization: Madrid, Spain, 2005; pp. 11-12. 
17. Pan, S.; Gao, M.; Kim, H.; Shah, K.; Pei, S.; Chiang, P. Advances and challenges in sustainable tourism toward a green economy. Sci. Total Environ. 2018, 635, 452-469. [CrossRef] [PubMed]

18. Tanguay, G.A.; Rajaonson, J.; Therrien, M.C. Sustainable tourism indicators: Selection criteria for policy implementation and scientific recognition. J. Sustain. Tour. 2013, 21, 862-879. [CrossRef]

19. Hunter, C. Sustainable tourism as an adaptive paradigm. Ann. Tour. Res. 1997, 24, 850-867. [CrossRef]

20. Ecological Tourism in Europe. Sustainable Tourism Development in UNESCO Designated Sites in South-Eastern Europe; Ecological Tourism in Europe (ETE): Bonn, Germany, 2009; p. 43.

21. Lim, C.; McAleer, M. Ecologically sustainable tourism management. Environ. Model. Softw. 2005, 20, 1431-1438. [CrossRef]

22. Clarke, J. A framework of approaches to sustainable tourism. J. Sustain. Tour. 1997, 5, 224-233. [CrossRef]

23. Vera, J.; Ivars, J. Measuring sustainability in a mass tourist destination: Pressures, perceptions and policy responses in Torrevieja, Spain. J. Sustain. Tour. 2003, 11, 181-203.

24. Hardy, A.; Beeton, R.J.S.; Pearson, L. Sustainable tourism: An overview of the concept and its position in relation to conceptualizations of tourism. J. Sustain. Dev. 2002, 10, 475-496. [CrossRef]

25. Butler, R.W. Seasonality in tourism: Issues and implications. In Seasonality in Tourism; Baum, T., Lundtorp, S., Eds.; Routledge: Oxford, UK, 2001; pp. 5-21.

26. Martín, J.; Jiménez, J.; Molina, V. Impacts of seasonality on environmental sustainability in the tourism sector based on destination type: An application to Spain's Andalusia region. Tour. Econ. 2014, 20, $123-142$. [CrossRef]

27. Jin, Q.; Hu, H.; Kavan, P. Factors Influencing Perceived Crowding of Tourists and Sustainable Tourism Destination Management. Sustainability 2016, 8, 976. [CrossRef]

28. Stokols, D. On the distinction between density and crowding: Some implications for future research. Psychol. Rev. 1972, 79, 275-277. [CrossRef]

29. Esser, A.H. Environment and the Social Sciences: Perspectives and Applications; American Psychological Association: Washington, DC, USA, 1972.

30. Schmidt, D.; Keating, J. Human crowding and personal control: An integration of the research. Psychol. Bull. 1979, 86, 680-700. [CrossRef]

31. Stokols, D. A social-psychological model of human crowding phenomena. J. Am. Plan. Assoc. 1972, 38, 72-83. [CrossRef]

32. Vaske, J.J.; Donnelly, M.P. Generalizing the encounter-norm-crowding relationship. Leis. Sci. 2002, 24, 255-269. [CrossRef]

33. Jurado, E.N.; Damian, I.M.; Fernández-Morales, A. Carrying capacity model applied in coastal destinations. Ann. Tour. Res. 2013, 43, 1-19. [CrossRef]

34. Bryon, J.; Neuts, B. Crowding and the tourist experience in an urban environment: A structural equation modeling approach. Retrieved July 2008, 22, 305-314.

35. Sun, Y.-Y.; Budruk, M. The moderating effect of nationality on crowding perception, its antecedents, and coping behaviours: A study of an urban heritage site in Taiwan. Curr. Issues Tour. 2017, 20, 1246-1264. [CrossRef]

36. Jin, Q.; Pearce, P. Tourist perception of crowding and management approaches at tourism sites in Xi'an. Asia Pac. J. Tour. Res. 2011, 16, 325-338. [CrossRef]

37. Rasoolimanesh, S.M.; Jaafar, M.; Marzuki, A.; Mohamad, D. How visitor and environmental characteristics influence perceived crowding. Asia Pac. J. Tour. Res. 2016, 21, 952-967. [CrossRef]

38. Hyun, S.S.; Kim, M.G. Negative effects of perceived crowding on travelers' identification with cruise brand. J. Travel Tour. Mark. 2015, 32, 241-259. [CrossRef]

39. Kainzinger, S.; Burns, R.C.; Arnberger, A. Whitewater boater and angler conflict, crowding and satisfaction on the North Umpqua River, Oregon. Hum. Dimens. Wildl. 2015, 20, 542-552. [CrossRef]

40. Manning, R.; Lawson, S.; Valliere, W. Multiple manifestations of crowding in outdoor recreation: A study of the relative importance of crowding-related indicators using indifference curves. Leisure/Loisir 2009, 33, 637-658. [CrossRef]

41. Moyle, B.; Croy, G. Crowding and visitor satisfaction during the off-season: Port Campbell national park. Ann. Leis. Res. 2007, 10, 518-531. [CrossRef]

42. Mudiyanselage, R.; Rathnayake, W. How does 'crowding' affect visitor satisfaction at the Horton Plains National Park in Sri Lanka? Tour. Manag. Perspect. 2015, 16, 129-138. 
43. Sayan, S.; Karagüzel, O. Problems of outdoor recreation: The effect of visitors' demographics on the perceptions of Termessos National Park. Turkey. Environ. Manag. 2010, 45, 1257-1270. [CrossRef]

44. Yagi, C.; Pearce, P.L. The influence of appearance and the number of people viewed on tourists' preferences for seeing other tourists. J. Sustain. Tour. 2007, 15, 28-43. [CrossRef]

45. Kyle, G.; Graefe, A.R.; Manning, R.E.; Bacon, J. Effect of activity involvement and place attachment on recreationists' perceptions of setting density. J. Leis. Res. 2004, 36, 209-231. [CrossRef]

46. Lee, H.; Graefe, A.R. Crowding at an arts festival: Extending crowding models to the front country. Tour. Manag. 2003, 24, 1-11. [CrossRef]

47. Arnberger, A.; Haider, W. A comparison of global and actual measures of perceived crowding of urban forest visitors. J. Leis. Res. 2007, 39, 668-685. [CrossRef]

48. Yildrim, K.; Akalin-Baskaya, A. Perceived crowding in a cafe/restaurant with different seating densities. Build. Environ. 2007, 42, 3410-3417. [CrossRef]

49. Arnberger, A.; Mann, C. Crowding in European forests: A review of recent research and implications for forest management and policy. Forestry 2008, 81, 559-571. [CrossRef]

50. Zhang, Y.; Li, X.R.; Su, Q.; Hu, X. Exploring a theme park's tourism carrying capacity: A demand-side analysis. Tour. Manag. 2017, 59, 564-578. [CrossRef]

51. Ryan, C.; Cessford, G. Developing a visitor satisfaction monitoring methodology: Quality gaps, crowding and some results. Curr. Issues Tour. 2003, 6, 457-507. [CrossRef]

52. Manning, R.E.; Ciali, C.P. Recreation density and user satisfaction: A further exploration of the satisfaction model. J. Leis. Res. 1980, 12, 329-345. [CrossRef]

53. Shelby, B. Crowding models for backcountry recreation. Land Econ. 1980, 56, 43-55. [CrossRef]

54. Noone, B.M.; Mattila, A.S. Consumer reaction to crowding for extended service encounters. Manag. Serv. Qual. 2009, 19, 31-41. [CrossRef]

55. Palau-Saumell, R.; Forgas-Coll, S.; Sanchez-Garciia, J.; Prats-Planagumà, L. Managing dive centers: SCUBA divers' behavioural intentions. Eur. Sport Manag. Q. 2014, 14, 422-443. [CrossRef]

56. Neuts, B.; Nijkamp, P.; Van Leeuwen, E. Crowding externalities from tourist use of urban space. Tour. Econ. 2012, 18, 649-670. [CrossRef]

57. Zhang, L.; Chung, S. Assessing the social carrying capacity of diving sites in Mabul Island, Malaysia. Environ. Manag. 2015, 56, 1467-1477. [CrossRef]

58. Machleit, K.A.; Eroglu, S.A.; Mantel, S.P. Perceived retail crowding and shopping satisfaction: What modifies this relationship? J. Consum. Psychol. 2000, 9, 29-42. [CrossRef]

59. Foster, J. Crowds and cruise ships have ruined Dubrovnik. The Telegraph. 23 June 2017. Available online: www.telegraph.co.uk/travel/destinations/europe/croatia/dubrovnik/articles/dubrovnik-facesovercrowding-cruise-ship-visitors- / (accessed on 30 January 2019).

60. Pallis, A.A.; Vaggelas, G.K. Cruise Shipping and Green Ports: A Strategic Challenge. In Green Ports; Elsevier: Radarweg, The Netherlands, 2019; pp. 255-273.

61. Papathanassis, A. High hopes \& high seas: The role and impact of cruise tourism in destination development. Presented at the International Tourism Studies Association (ITSA) Biennial Conference, Greenwich, UK, 19 August 2016; Available online: www.papathanassis.com/images/dlfiles/highhopes.pdf (accessed on 13 February 2019).

62. Klein, R.A. Keeping the Cruise Tourism Responsible: The Challenge for Ports to Maintain High Self Esteem. 2009. Available online: www.cruisejunkie.com/icrt2.pdf (accessed on 18 January 2019).

63. Klein, R.A. Responsible cruise tourism: Issues of cruise tourism and sustainability. J. Hosp. Tour. Manag. 2011, 18, 107-116. [CrossRef]

64. Castillo-Manzano, J.I.; López-Valpuesta, L. What does cruise passengers' satisfaction depend on? Does size really matter? Int. J. Hosp. Manag. 2018, 75, 116-118. [CrossRef]

65. Brejla, P.; Gilbert, D. An exploratory use of web content analysis to understand cruise tourism services. Int. J. Tour. Res. 2014, 16, 157-168. [CrossRef]

66. Buzova, D.; Sanz-Blas, S.; Cervera-Taulet, A. 'Tour me onshore': Understanding cruise tourists' evaluation of shore excursions through text mining. J. Tour. Cult. Chang. 2018, 1-18. [CrossRef]

67. Papathanassis, A. Cruise tourism management: State of the art. Tour. Rev. 2017, 72, 104-119. [CrossRef]

68. Smith, A.E.; Humphreys, M.S. Evaluation of unsupervised semantic mapping of natural language with Leximancer concept mapping. Behav. Res. Methods 2006, 38, 262-279. [CrossRef] 
69. Sotiriadou, P.; Brouwers, J.; Le, T.A. Choosing a qualitative data analysis tool: A comparison of NVivo and Leximancer. Ann. Leis. Res. 2014, 17, 218-234. [CrossRef]

70. Amini, M.; Bienstock, C.C.; Narcum, J.A. Status of corporate sustainability: A content analysis of Fortune 500 companies. Bus. Strategy Environ. 2018, 27, 1450-1461. [CrossRef]

71. Daniel, L.; Medlin, C.J.; O'Connor, A.; Statsenko, L.; Vnuk, R.; Hancock, G. Deconstructing the entrepreneurial ecosystem concept. In Entrepreneurial Ecosystems; Springer: Cham, Switzerland, 2018; pp. 23-44.

72. Kim, D.; Kim, S. Sustainable supply chain based on news articles and sustainability reports: Text mining with Leximancer and DICTION. Sustainability 2017, 9, 1008. [CrossRef]

73. Wu, M.Y.; Wall, G.; Pearce, P.L. Shopping experiences: International tourists in Beijing's silk market. Tour. Manag. 2014, 41, 96-106. [CrossRef]

74. Bonilla-Priego, M.J.; Font, X.; del Rosario Pacheco-Olivares, M. Corporate sustainability reporting index and baseline data for the cruise industry. Tour. Manag. 2014, 44, 149-160. [CrossRef]

(C) 2019 by the authors. Licensee MDPI, Basel, Switzerland. This article is an open access article distributed under the terms and conditions of the Creative Commons Attribution (CC BY) license (http:/ / creativecommons.org/licenses/by/4.0/). 